\title{
CHANGE MANAGEMENT PROCESS THROUGH TOURISM IN FINANCE ASPECTS ACCORDING TO THE TRANSNATIONAL PROJECT AS THE NEW SILK ROAD
}

Iryna Fyshchuk, $\mathrm{PhD}$, assistant professor, National Academy for Public Administration under the President of Ukraine, Kyiv, Ukraine

Giese Roland, Doctor of economics, Professor University of Applied Sciences Zittau-Görlitz, Germany

Tussupova Layla, Doctor of economics Professor, Turan University, Kazakhstan

Finances in the international tourism are under the influence of globalization and integration processes the most dynamic development and becoming one of the influential factors on which it dependson growth of economy, increase of competitiveness of the country in world markets, improving the well-being of the population. Globalization refers to the process of globalization economic, political and cultural mutual rapprochement and education interconnections. The processes of globalization in the tourism market are characterized by change of technologies as change management approach, internationalization of business activity, modernization of transport infrastructure, the creation of a regulatory mechanism.

Keywords: international finances, change management processes, transnational projects, tourism.

\section{Introduction}

Change management is an important aspect general management of organizations, as globalization, unrestricted distribution and access to information, increasing competition has led to increase finances flows through tourism sphere. 
Today only technologically and structurally flexible and innovative education can keep up the market and succeed today. However, the successful implementation of the desired innovations requires relevant knowledge and experience in the field of change management. Indeed, according to studies conducted, this task is rather difficult. It is not enough to concentrate on the so-called rigid factors, but for the first time it is necessary to realize that no change can be realized if the staff of the enterprise does not consider it expedient.

Change management is a process to overcome non-acceptance and unpreparedness to their organizational components - the difficulties that appear in the social, technical, organizational, economic legal, finance and touristic spheres. The most important is the social sphere, in which there are a lot of discrepancies and perturbations, in the connection with which this sphere should occupy a priority place in the implementation of improvements and become the main source of search for opportunities to successfully manage the processes of change in organizations.In the center of substantive interest processes of change are people - the key a factor in their success.

Today, however, one should take into account the emergence of technical and organizational innovations that themselves complement and create changes that penetrate the entire organization. According to the concept of the relationship of man with others the world and the ability to adapt to change, management of this process becomes a priority for science, creativity, innovation and creative thinking of people, and the future belongs to the organizations in which the formula will be implemented: human - the highest value. Nowadays, people desire to travel and to discover the world and do changes and create them, thereby creating a large financial industry with cash flows.

Attention is also drawn to the elaboration of the competencies of persons implementing change, informing about changes in their participants, the issue of implementing changes so thatthe party member wanted to become the object of the process of assimilation and did it more voluntarily than under administrative coercion.

These problems of theoretical and methodological nature are importantthe conditions for the successful management of changes in 
organizations in order to develop themconditions of dynamic changes in the market environment, which became the main, motivethe choice of the topic and the formulation of the purpose and objectives of the study.

The last quarter of the twentieth century and the beginning of the twenty-first century have passed under the sign of accelerated development tourism, which has transformed it into a global mass, forms and technologies organization of recreation phenomenon. Despite the planetary scale, tourism has remained regional and national content. The tourist industry of the world offering unified recreation and service systems operates regional natural differences and the national and cultural identity of ethnic groups and local communities, which in many cases becomes the main motive of travel. In the world economic practice is difficult to find another type of productive activity, which simultaneously contributes to the globalization of the economy and the development of regions.

\section{Main material}

Globalization and regionalization are part of a single process of international development tourism, which makes it a unique economic tool capable of forming production systems of an international nature and maintain local significance. In tourism, the company's exit beyond the state borders is a common practice, which due to the specifics of the tourist product. The initiative of internationalization production in tourism belongs to countries that generate powerful tourist flows, because it gives them the greatest benefit. In North America, this is the United States and Canada, in Europe - Germany, Britain and France, in Asia - Japan and China.

The conclusion of global unions is common in various sectors of the tourism industry practice. A striking example of the activities of such unions is the global computer reservation systems for a wide range of tourist goods and services - from aviation flights, transfers by rail and the purchase of package tours, to rent a car, pre-order a place at the hotel or tickets for a football match or a concert. All of these create finance flows in touristic industry.

The manifestation of the globalization processes in tourism is the implementation of joint projects, which involve the involvement of 
natural, cultural-historical and logistical resources of several countries. For example, the implementation of the ecotourism project "World of Maya" involves participation in almost all countries of Central America. Nowadays, it could be some new touristic projects that will control touristic new routes.

In recent years, the tourism industry has become an important social and political phenomenon influence on the economy of many developed countries. Modern tourism, without a doubt, integrates practically all branches. Annually in the world almost done one billion tourist trips. Tourism, certainly one of the most profitable branches. Tourism forms up to $10 \%$ of the gross national product of the EU for example. In the developed countries of the world tourism promotes socio-economic development countries.

According to the forecasts of the WTO, the number of travelers in the next five years will increase to 1.6 billion people a year. It is assumed that the daily expenses of tourists, with the exception of expenses on air tickets, will grow to about five billions of dollars a day. Outbound tourism also will not stand still. The most massive tourist flows are expected from the USA, Japan, China, and Germany.

The situation of uncertainty frustrates potential foreign tourists. And consequently, in order to improve the situation, it is necessary first of all, to conduct a competent informational a policy aimed at creating a positive image of the country. Tourism is one of the most promising directions of socio-economic development of the regions. Today is hampered by the development of tourism many factors, including imperfections legislative framework, and the limited range of services offered, and lack of funds for the reconstruction of historical and historical monuments architectural art and high-grade information about possible tourist routes. This list can be further continuing.Among the important areas of work the tourism development is a powerful information policy.

According to the World Tourism Organization, finances that people spent in 2016 through tourism have such gradation as: 


\begin{tabular}{|c|c|}
\hline Country & $\begin{array}{c}\text { Sum of money spent through tourism } \\
\text { in 2016, billion dollar USA }\end{array}$ \\
\hline China & 261 \\
\hline USA & 122 \\
\hline Germany & 81 \\
\hline UK & 64 \\
\hline France & 41 \\
\hline
\end{tabular}

Source: World Tourism Organization: http://cf.cdn.unwto.org/sites/all/ files/pdf/annual_report_2016_web_0.pdf)

It is very interesting to discover what exactly countries are getting such finances. According to the World tourism organization, the top destinations of travelers were done to such countries as France, USA, Spain, China and Italy. In the table 2 there is quantity of tourists and list of countries.

Table 2

\begin{tabular}{|c|c|}
\hline Country & $\begin{array}{c}\text { Top tourist's destinations, } \\
\text { million people in 2016 }\end{array}$ \\
\hline France & 84,5 \\
\hline USA & 77,5 \\
\hline Spain & 68,5 \\
\hline China & 56,9 \\
\hline Italy & 50,7 \\
\hline
\end{tabular}

Source: World Tourism Organization: http://cf.cdn.unwto.org/sites/all/ files/pdf/annual_report_2016_web_0.pdf 
According to quantity spent finances from tourists of China all round the world, some countries started to implement such changes as: translation of the main information on the scoreboard in the airports in Chinese language, also fast food cafes started implement their menu for Chinese travelers with translation on Chinese language as well. It means that our world is under new global changes with new finance cash flows and global players.

Some of European cities started even take payments in the airports and cafes from Chinese Union pay cards and Alipay system, all services were implemented for Chinese tourists. So, there is new player on the financial market with MasterCard, Visa Card and now Union Pay card.

New Silk Project that was announced in 2013 and more formal during forum in May 2017 has declared the ambitious plan for future development in the world that could connect a lot of countries with hug infrastructure and logistics projects that could raise Chinese travelers and finances cash flows in the frame of the planned routes according to the One Belt and One Road project.

Today, the world economy is more than ever dependent on the efficiency of the movement of people and goods. Competitive struggle in the logistics market is in full swing, which reflects numerous opportunities and equally numerous problems. In recent years, Asia - the largest emerging market in the world - is experiencing a striking rise. The Asian logistics market and supply chain, although lagging behind, can change the situation altogether. Experts suggest that one of the main determining tendencies will be the area of integrated contract logistics and outsourcing.

New transnational project provides investment and trade cooperation is a major task in building the Belt and Road. It was created New Silk Road Fund that should strive to improve investment and trade facilitation, and remove investment and trade barriers for the creation of a sound business environment within the region and in all related countries. Management of New Silk Road project will discuss with countries and regions along the Belt and Road on opening free trade areas so as to unleash the potential for expanded cooperation. Countries along the Belt and Road should enhance customs cooperation such as information exchange, mutual recognition of regulations, and mutual assistance in law enforcement; 
improve bilateral and multilateral cooperation in the fields of inspection and quarantine, certification and accreditation, standard measurement, and statistical information; and work to ensure that the WTO Trade Facilitation Agreement takes effect and is implemented. New Silk Road management should improve the customs clearance facilities of border ports, establish a "single-window" in border ports, reduce customs clearance costs, and improve customs clearance capability.

Main idea of the New Silk Road project is to connect whole world through infrastructure, cultural and finance projects. On the figure 1, it is how looks the process of linking China to Europe through Central Asia by creating a land-transport network that cuts thousands of miles off the traditional sea routes from China's east coast for transporting oil and gas and other natural resources imports. With the help of developing such a project it will be easier to travel andtourist flows will increase.Using such linking strategy it will economically better links to enrich China's underdeveloped western border regions to reduce ethnic tensions.

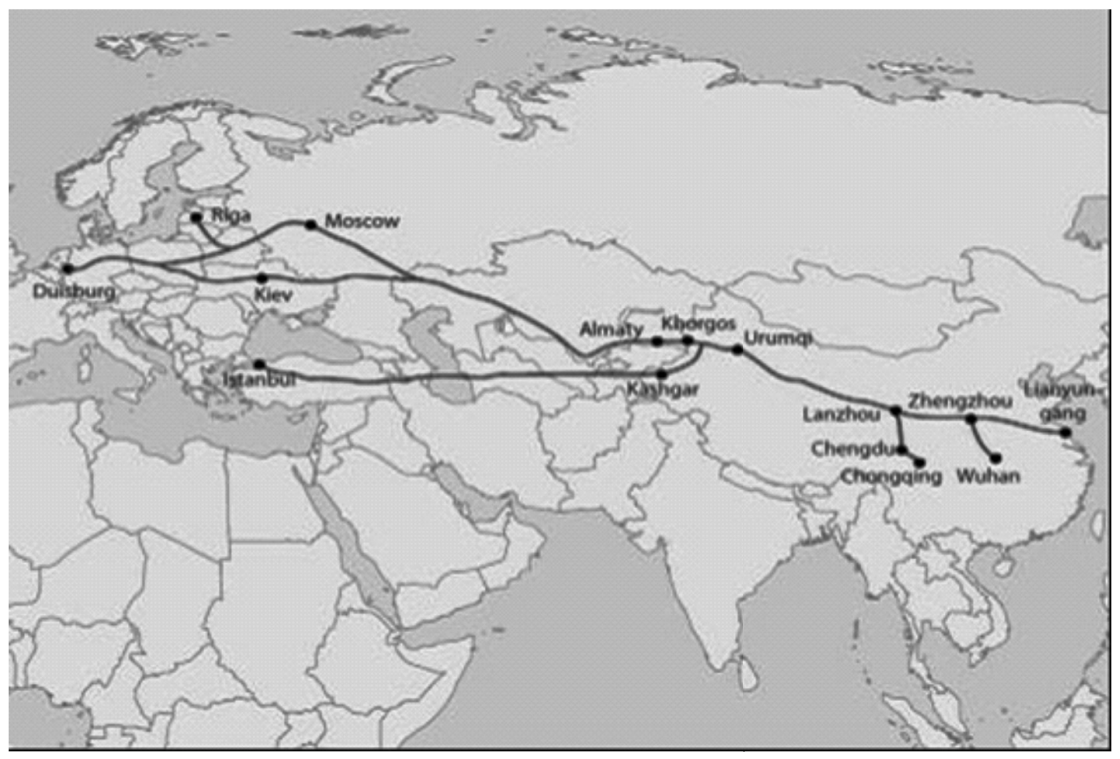

Figure 1. Map of the New Silk Road project.

Source: Wikipedia. 
According to analysis of China's foreign contracted and completed projects - raising numbers of new foreign contracts since announcement are continuous to grow and foreign revenue showing fluctuations in an increasing direction.

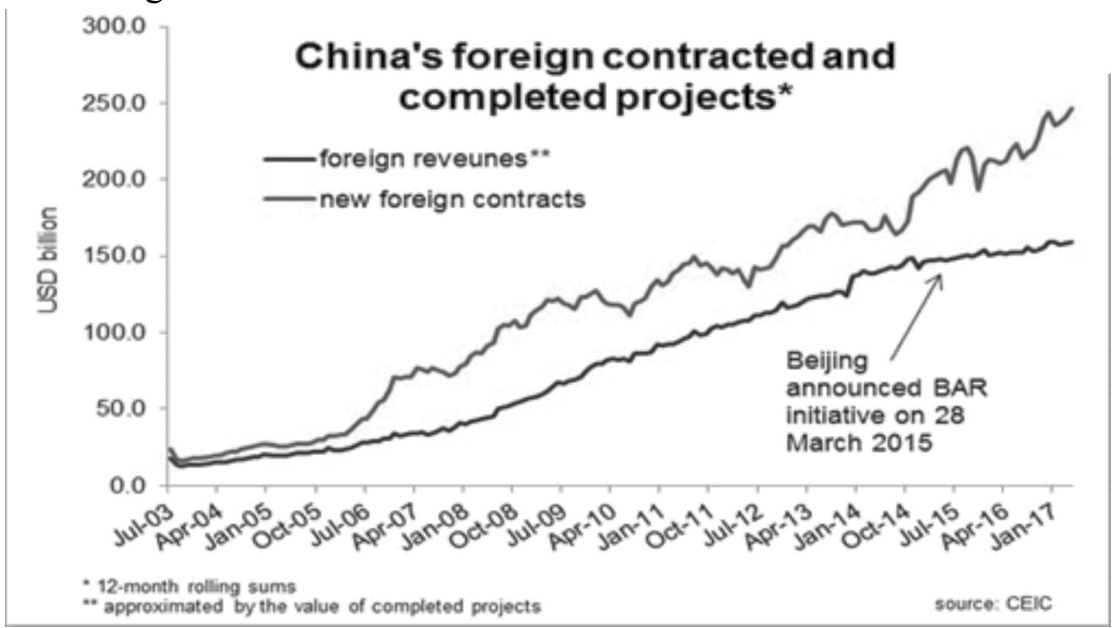

Figure. 2. China `s foreign contracted and completed projects in Belt and Road initiative

Source: CEIC - A Euromoney Institutional Investor Company

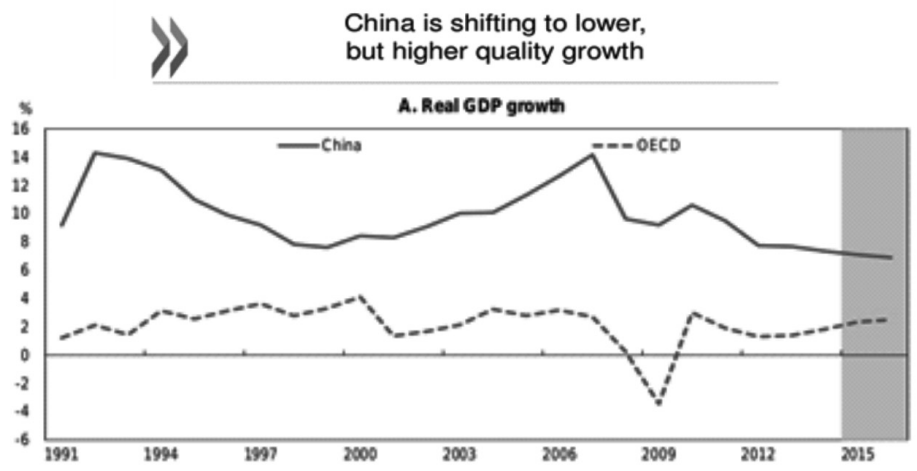

Figure 3. Growth GDP of China and OECD countries.

Source: OECD Economic Outlook Database. 
China is shifting to lower but higher quality growth of gross domestic product (GDP) comparing with 34 members - countries in the Organization for Economic Cooperation and Development.

As main ideas and goals of Chinese government that they have declared domestically:

- moderate prosperity for all by 2020

- China is a modern State in all respects by 2049.

Major challenges:

- Navigate the economic transition

- Rehabilitate the environment, to change situation with pollution.

First step of internationalization is trade. Tourism is trade in services as hotel, restaurants, transport, touristic marsh routes, museums, education, conferences.

For tourism is very important $\bullet$ an inclusive and sustainable sector based on:

- human rights;

- social and economic justice and equality in the country/city/region;

- responsible and sustainable planning of the routes;

- the involvement of all stakeholders, including host;

- communities and disadvantaged groups of society;

- provision of fair access to quality training;

- employment opportunities for youth and women during the traveling destination.

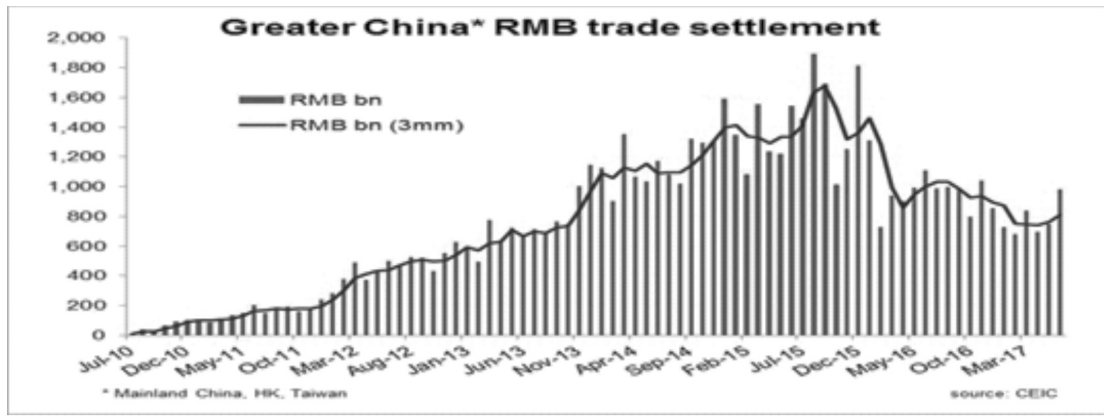

Figure 4. Chinese currency - rmb (yuan) trade settlement 2010-2017

Source:CEIC - A Euromoney Institutional Investor Company 
Trade settlement in RMB surged from $10 \mathrm{bn} /$ month in 2010 to a peak of RMB 2 trn/month in mid-2015. Over RMB3 trn swap lines signed with more than thirty central banks. RMB in the SDR is a recognition of its international role.

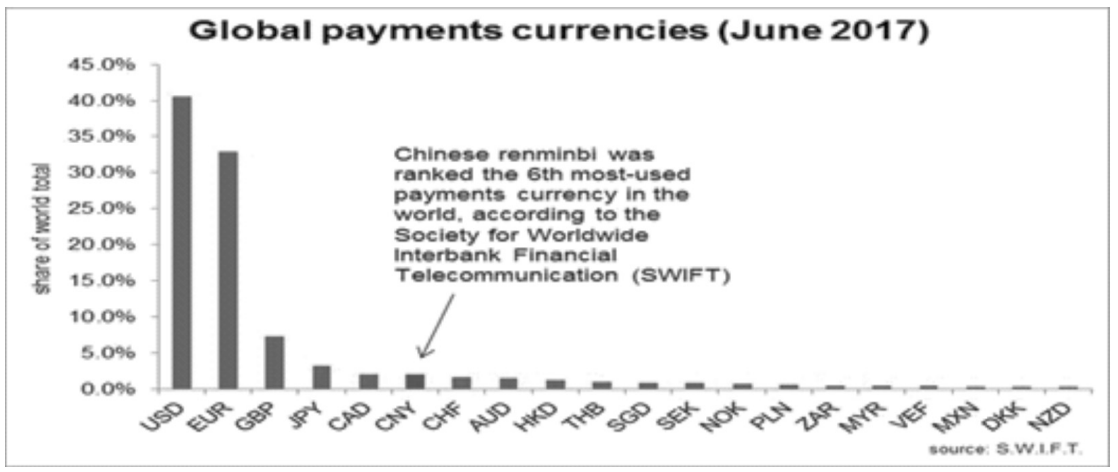

Figure 5. Global payments currencies (June 2017)

Source: SWIFT

The second step - internationalization of RMB (yuan) as global player in the currency market. That will need such actions as:

- The first step is hitting a limit; current account surplus is not conducive to internationalization;

- A demand for money approach to analyze the next step (Transactional demand - foreign trade; Precautionary demand - reserve currency, savings; Speculative demand - investment);

- Developing precautionary and speculative demand for the RMB; i.e. using RMB for financial transactions;

- Need a deep and mature Chinese capital market, with RMB financial instruments and hedging tools made available to global players in both the onshore and offshore markets.

According to the New Silk Road initiative they should increase cooperation in supply chain safety and convenience, improve the coordination of cross-border supervision procedures, promote online checking of inspection and quarantine certificates, and facilitate mutual recognition of authorized economic operators. And they should make 
lower non-tariff barriers, jointly improve the transparency of technical trade measures, and enhance trade liberalization and facilitation.

Challenges for the European countries and other countries that will be involved in the New Silk Road project - how to exist with such huge investments that Chinese government plan toimplement (it is over than 2.5 trillion dollars) for embody on the project andin which way it will regulate such investments.

The New Silk Road will expand the scope and scale of bilateral currency swap and settlement with 6other countries along the Belt and Road, open and develop the bond market in Asia, make joint efforts to establish the Asian Infrastructure Investment Bank and BRICS New Development Bank, conduct negotiation among related parties on establishing Shanghai Cooperation Organization (SCO) financing institution, and set up and put into operation the Silk Road Fund as early as possible. We should strengthen practical cooperation of ChinaASEAN Interbank Association and SCO Interbank Association, and carry out multilateral financial cooperation in the form of syndicated loans and bank credit. We will support the efforts of governments of the countries along the Belt and Road and their companies and financial institutions with good credit-rating to issue Renminbi bonds in China. Qualified Chinese financial institutions and companies are encouraged to issue bonds in both Renminbi and foreign currencies outside China, and use the funds thus collected in countries along the Belt and Road. All of these signals mean that touristic business climate will increase and China will have more finance power in the world.

Financial resources in the New Silk Road project include such institutions as:

- the Silk Road Fund with 40 billion US dollars this fund is open and involves the participation of investors in their activities, however, it is not yet clear who will invest money and how to attract them;

- Asian Infrastructure Investment Bank with 57 counties-participants that signed memorandum 20 of April 2015 with 100 billion US dollars;

- Exim Bank of China will allocate 60 billion US dollars for projects;

- State Development Bank of China - 110 billion US dollars.

The New Silk Road aims at building a massive network of trade and infrastructure for China to expand into countries in Asia, Central Asia, 
the Middle East, Europe, and Africa. It should also go a long way to deepen yuan internationalization.

Investment projects that had been started according to the New Silk Road plan:

- Kenya Part of the initial fund was invested in the construction of a Mombasa-Nairobi Standard Gauge Railway.

- Pakistan US\$1.65-billion investment in the Karrot Hydropower Project and other hydropower projects in the region as part of the ChinaPakistan Economic Corridor.

- Russia Acquisition of 9.9\% of Yamal LNG project, a liquefied natural gas project in Sabetta, located north-east of the Yamal Peninsula, from Novatek.

All of these projects increase numbers of travelers and finance flows to those regions.

To rebalance growth distribution, Beijing has been implementing a "Go West" development strategy since the 2000s. Fiscal spending and infrastructure investment have been the pillar policies to redirect industrialization inland.

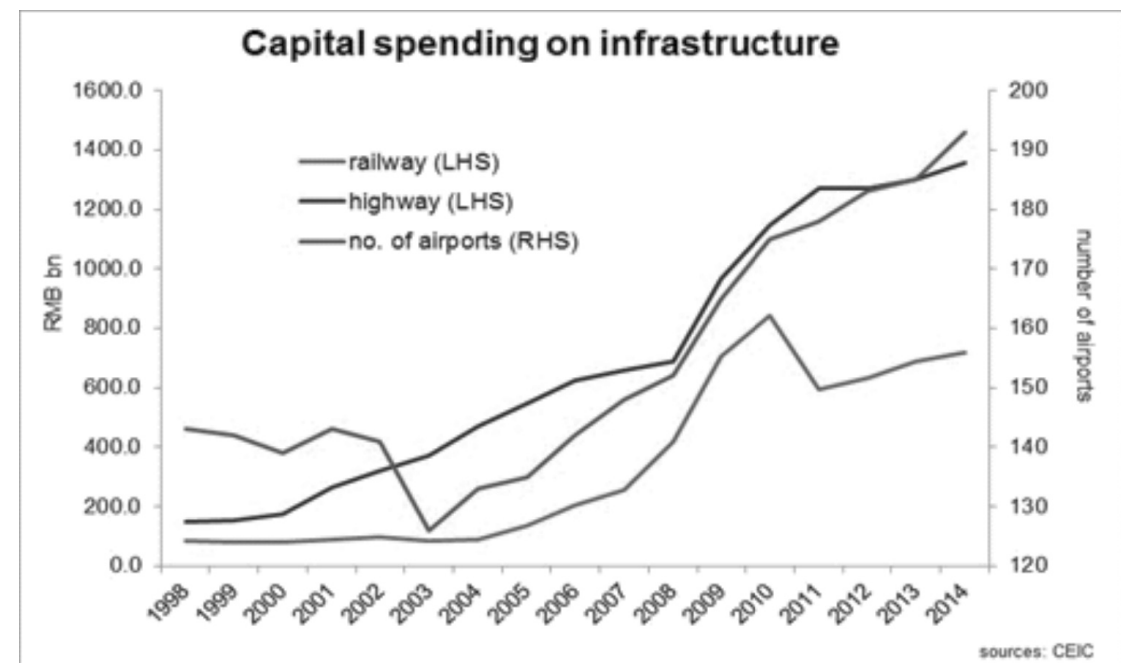

Figure. 6. Capital spending on infrastructure

Source: CEIC - A Euromoney Institutional Investor Company 
China is going through a "hollowing-out" process with industrialization moving inland, the tertiary sector is now bigger than the secondary sector. These changing dynamics are essential for eventual structural shift towards a consumption-based economy. Urbanization follows industrialization as labor and consumption move to areas where jobs exist, and jobs are created where investment exists. Now a lot of tourist from whole the world is searching for an opportunity to see the country and try to find a job in a big city of China as it is a good experience to learn Chinese language and earn good money.

Changes process in the New Silk Road provides the program of strengthen financial regulation cooperation; establish an efficient regulation coordinationmechanism in the region. New Silk Road management plan to improve the system of risk response and crisismanagement, build a regional financial risk early-warning system, and create an exchange andcooperation mechanism of addressing crossborder risks and crisis. The main ideas of their management - increase cross border exchange and cooperation between credit investigation regulators, credit investigationinstitutions and credit rating institutions. The role of the Silk RoadFund and that of sovereign wealth funds of countries along the Belt and Road, and encouragecommercial equity investment funds and private funds to participate in the construction of keyprojects of the Initiative.

According to the New Silk Road plan they plan to increase tourists flow through the education programs. They plan to send more students to each other's countries, and promote cooperation in jointly running schools. China will provide 10,000 government scholarships to the countries along the Belt and Road every year. They will hold culture years, arts festivals, film festivals, TV weeks and book fairs in each other's countries; cooperate on the production and translation of fine films, radio and TV programs; and jointly apply for and protect World Cultural Heritage sites. New Silk Road fund will also increase personnel exchange and cooperation between countries along the Belt and Road.

The New Silk Road Fund will enhancecooperation in and expand the scale of tourism; hold tourism promotion weeks and publicity months in each other's countries; jointly create competitive international 
tourist routes and products with Silk Road features; and make it more convenient to apply for tourist visa in countries along the Belt and Road. They will push forward cooperation on the 21st-Century Maritime Silk Road cruise tourism program. Also they will carry out sports exchanges and support countries along the Belt and Road in their bid for hosting major international sports events.

With such scales, temps and ambitions we can see very soon how Chinese language will be as global language in the world.

Change management process is acting in the new paradigm of development and taking to account new challenges that world dictate to human and companies through some factors such as control, interoperability, collaboration, economization.

Table 3

\section{Factors in the success of the simplification of procedures in the change management processes}

\begin{tabular}{|l|l|}
\hline \multicolumn{1}{|c|}{ Factors } & \multicolumn{1}{c|}{ Simple mentation of procedures } \\
\hline Control & $\begin{array}{l}\text { Secure data management data owner; } \\
\text { Enables setting a subset of data that ensures management } \\
\text { and collaboration }\end{array}$ \\
\hline Interoperability & $\begin{array}{l}\text { Maximum compliance with standard data and minimize } \\
\text { data redundancy; } \\
\text { Support the development of the individual, but it is } \\
\text { compatible content business by providing the appropriate } \\
\text { technical solutions }\end{array}$ \\
\hline Collaboration & $\begin{array}{l}\text { Providing collaborative environment for corporations, } \\
\text { organizations, project teams and independent parties; } \\
\text { Supply of technical equipment for joint work, such as the } \\
\text { central repository and version control }\end{array}$ \\
\hline Economization & $\begin{array}{l}\text { Save time by reusing instead of retyping data standards; } \\
\text { Minimize upgrades and data migration efforts }\end{array}$ \\
\hline
\end{tabular}

Source: own work. 
Analyzing the state of modern tourism it should be emphasized that The Asia-Pacific region is gradually increasing its pace and it's the share in international tourism increases every year. It due to the pace and rapid dynamics of economic development, the degree of concentration of demographic potential and growth the population in the largest countries (China, India, Indonesia, etc.), as well active tourism policy, which began to hold countries region, thus attracting large numbers of tourists. According to forecasts UNWTO, in 2016 the number of arrivals will increase in the Asia-the Pacific and Africa at 4\% - 6\%, they will be follow the American region and Europe (2\% - 4\%).

Based on research on the dynamics of modern development International tourism should be expected that tourism in the XXI century will be engine of the world economy. According to UNWTO's longterm forecast "Tourism: the prospect of 2030", in 2030 the number of international tourist arrivals will reach 1.8 billion. This means that after two decades 5 million people every day will cross international frontiers for the purpose leisure, business or other purposes such as visiting friends and friends' relatives on the countries of Asia, Latin America, Central and Eastern Europe, East-Mediterranean Europe, Middle East and North America Africa will have an average of 30 million arrivals per year. Their share is expected to reach $58 \%$.

The global market will increase share Asia-Pacific region (from $22 \%$ in 2010 to $30 \%$ in 2030), The Middle East (from $6 \%$ to $8 \%$ ), and Africa (from $5 \%$ to $7 \%$ ). It will be out further reducing the share of Europe (from $51 \%$ to $41 \%$ ) and American region (from $16 \%$ to $14 \%$ ), mainly because of more the slow pace of growth in North America. In the next two decades, a significant proportion of arrivals will be provided by countries in the Asia-Pacific region that have a growth rate of 5\% per year and generating on average 17 million additional international arrivals each year, on the second place in Europe (giving an average of 16 million additional international arrivals per year with growth rates of $+2.5 \%$ per year).

Analyzing the state and prospects of development of modern international tourism can be distinguished by long-term factors affecting him. Namely: economic, scientific and technological progress, 
demographic, social, cultural, international. These constantly operating factors in a certain periods may be aggravated or weakened by various less scale and short-term market conditions. At this development of world tourism shows that for the modern stage characterized by a rapid recovery of its volumes in the unfavorable the situation.

In each tourist facility there are conditions for the development of the sphere of tourist services. therefore, in each case, along with the typical variants of the structure and functioning of the tourist facility, it is necessary to create special options for the organization of services, use of natural potential, it is necessary to formulate specific variants of organization of services, use of natural potential, variants of sources of financing of construction and current activity. Taking into account regional peculiarities, along with the consideration of specific variants of its functioning and development, requires the assessment and accounting of resource constraints and factors that determine the volume of supply and demand for services, tariff levels for services, as well as the assessment of the potential of the tourist facility and the degree of its use.

In conditionsthat we have nowadays, the criteria for the optimal development of a tourist facility are purely economic criteria: maximization of profits, maximization of return on investment. Dynamic optimization models for the development of economic systems are subject to dynamic optimality criteria. Socio-economic assessments of the options for the development of the system are given for a certain period of time reflecting the process of formation of these estimates in time. In this case, the procedure for comparing and bringing the time-consuming costs and results to a single point of time is played by the procedure of discounting. In the dynamic criterion of optimal development of a tourist object it is necessary to compare and estimate current costs and investments in the new construction and reconstruction of its objects with the results of its functioning during the development of the tourist object and its exit on the optimal mode of operation.

To solve the problem of optimizing processes in the field of tourism business as finance correlation we will introduce the following model. For the cost of each business in the general range of travel services the 
organization calculates the proportion of the specific gravity, which is calculated for formula (1):

$$
\mathrm{Vi}=\mathrm{Yi} / \mathrm{Yo}^{\prime} 100 \% \text { (1) }
$$

Where $\mathrm{Vi}$ - specific gravity of the business unit in the total volume of tourist sales services during the base period (proposed period - 1 year);

Yo - total volume of sales of tourist services in the base period (thousand dollars/euro...);

$\mathrm{Yi}$ - the volume of sales of tourist services of the same group for the same period. At the same time $\mathrm{Yo}=\Sigma \mathrm{Yi}$.

As justification for choosing the parameter $\mathrm{V}(\%)$, the following should be noted reasons:

- exactly calculate market share (even regional) at the moment, it is extremely difficult if at all possible;

- the volume of realization of the services of the enterprise actually is its volume (enterprises) of the market in each particular period.

- for each enterprise, the key task is absolute growth, its own sales volumes, even if its share in the market is reduced;

- in the conditions of dynamic and not always predictable changes in market capacity.

To characterize the contribution of each business unit in the total change the tempo of volumes of realization of tourist services is calculated the indicator of the specific the weight of the business unit at the rate of change in volumes over the base period for linear trend (TI).

This parameter is calculated by the formula (2):

$\mathrm{Ti}=\mathrm{Ai} / \mathrm{Ao}^{*} 100 \%,(2)$

where $\mathrm{Ti}$ - specific gravity of the business unit in the rate of sales volumes change tourist services during the base period according to the linear trend $(\%)$;

Ao - coefficient of trend of total sales in the base period;

$\mathrm{Ai}$ - coefficient of trend of the same group of services during the base period.

Formula of linear trend of the volume of realization of tourist services is equation of polynomial of the first degree (3):

$\mathrm{Yo}=\mathrm{Ao} * \mathrm{X}+\mathrm{B} 0$, (3)

where Yo - estimated sales volume (thousand dollars/euro...); 
$\mathrm{X}$ - settlement period (month);

Ao is an equation parameter that can be interpreted as a calculated change (growth or decrease) in the volume of sales of tourist services compared with previous period;

Bo - parameter of the equation, which can be interpreted as theoretical volume sales in the initial period (thousand dollars/euro...); in the first month).

Under this condition, the trend equation for each and every one business unit will have similar look (4):

$$
\mathrm{Yi}=\mathrm{Ai}^{*} \mathrm{X}+\mathrm{Bi}(4)
$$

Since Yo $=\Sigma Y$, then in accordance with the property of linear additivity functions $\mathrm{Ao}=\Sigma \mathrm{Ai}$, the unit increment of the total volume of sales consists of unit increments (with both signs) of sales volumes of all business units, included in the range of tourist organizations.

Thus, change management processes and finances flows respectively and taking into account the forecasts of UNWTO and analyzing the international one market of tourist services, it is possible to identify the following trends of tourism development before 2020 such as:

- The most active tourists will be two age groups: the elderly and young people;

- The demand for tourism related to the visit of the prominent ones will continue to grow cultural monuments, as well as active recreation;

- The state of the environment will be one of the dominant factors in attracting tourists, especially in rural and coastal areas;

- The geography of international tourism will be determined as a priority for tourists' factors of attractiveness of certain regions, countries. In the future, the main source satisfaction of tourist needs will remain natural potential;

- There will be an attraction to the virgin nature, which is associated with the concept of beauty, and

- in this connection, first of all, ecological tourism will develop;

- Development of non-traditional (extreme) types of tourism, distribution of individual tourist travel, the development of elite (hunting, scientific, congress), space tourism; 
- in Europe will have to withstand fierce competition for tourism profits, which, in turn, will require the European tourism industry to improve quality provided services;

- The cost of all types of travel and, above all, transportation costs, will be increase faster than other family budget articles. Travel will become more frequent but less prolonged, because the cost of one trip will be reduced. In general, however travel expenses will increase due to the consumption of more quality rest;

- The number of trips will increase due to intercontinental travel with Europe to America, Asia and Oceania;

- The use of air transport will be expanded faster thanks to increase in the number of convenient direct flights.

\section{Conclusion}

For the tourism and finances very important factors are stability as a necessary condition successful development and safety and security concerns and the temptation to buildnew barriers to travel; the technological revolution; and charting a course toward sustainable development.

The impact of globalization processes on international tourism in the world will increase, which is connected with the expansion of international tourism contributions to the balance of payments of the country, ensuring employment, promoting diversification of the economy, as well rational use of recreational resources. International tourism business will continue to modify, expand and grow become. In an era of globalization, markets have become fragile. What is today with works well, may not work in the future at all.

An analysis of the state of modern international tourism gave the opportunity to establish that today tourism is one of the largest and dynamic industries that are actively developing, has positive dynamics. But for its further development it needs state support, simplification of tourist formalities, Complex work to improve the material base tourism, training of highly skilled personnel for the sphere of tourism, maximizing the use of information and communication technologies, carrying out large-scale advertising campaigns.

Financial figures show the growth of Chinese tourists in the world and the inflow of tourists to China, which gave impetus to government 
initiatives to rebuild the New Silk Road Project, which could become a new global challenge with a new order and new change management processes that will be implemented in the companies, countries. Ambitious finance resources of the New Silk Road fund will connect regions with infrastructure projects and it will create new tourists routes for travelers and spreading culture and Chinese language and Chinese methods of payments.

\section{References}

1. "Silk Road Fund's 1st investment makes China's words into practice". Xinhua. Available at http://news.xinhuanet.com/english/201504/21/c_134171060.htm [in English].

2. Jeremy Page (8 November 2014). "China to Contribute $\$ 40$ Billion to Silk Road Fund". WSJ. Available at: https://www.wsj.com/articles/china-tocontribute-40-billion-to-silk-road-fund-1415454995

3. "China's $\$ 40$ b Silk Road Fund signs MoU with Russian firms". China Daily. September 3, 2015. Motion resources.Available at: https://www.rt.com/ business/256877-russia-china-deals-cooperation/ [in English].

4. Action plan on the Belt and Road Initiative Retrieved from http:// english.gov.cn/archive/publications/2015/03/30/content_281475080249035. htm [in English].

5. Europe and China's New Silk Roads, Mercator Institute for China Studies, December 2016, Retrieved from https://www.merics.org/en/merics analysis/merics reports/europe and chinas new silk road/ [in English].

6. Chinas New Silk Road is Getting Muddy, Foreign Policy, January 2017, Retrieved from http://foreignpolicy.com/2017/01/09/chinas new silk road is getting muddy/ [in English].

7. Chi Lo(14 June 2017) The Belt and Road Strategic Plan. For professional investors.https://docfinder.is.bnpparibas-ip.com/api/files/1E3806D2-6DA74FE4-B42A-FF071A566B6D [in English].

8. Chi Lo (13 January 2016) Mega Trends of China (3): Available at: https://docfinder.is.bnpparibas-ip.com/api/files/8AD8F6C8-04D9-4F47-BA682282A1BA61A1 [in English].

9. Chinese Ways of Empire, Then and Now, The New York Times, June 2017, Retrieved from https://www.nytimes.com/2017/06/30/opinion/china hong kong xi jinping.html?mcubz=1[in English]. 
10. Xi Jinping Positions China at Center of New Economic Order, The New York Times, May 2017, Retrieved from https://www.nytimes.com/2017/05/14/ world/asia/xi jinping one belt one road china.html?mcubz=1 [in English].

11. Official site Silk Road Project Retrieved from http://www.silkroadfund. com.cn [in English].

12. Official siteAsian Infrastructure Investment Bank Retrieved from https://www.aiib.org/en/index.html [in English].

13. World Tourism Organization Retrieved from http://cf.cdn.unwto.org/ sites/all/files/pdf/annual_report_2016_web_0.pdf) [in English].

14. Hansen V. (2012). The Silk Road: A New History : Oxford University Press, 320 p. [in English].

15. Fyshchuk I. (2017). Geopolitical role of the new silk road project in the financial aspects, Mlada Veda Young Science, ISSN 1339-3189 [in Ukrainian].

16. Fyshchuk I. (2017). Changes processes in logistics projects according to the New Silk Road Initiative in Ukraine in the context of the integration to the legal aspects of European Union, International Journal of Legal Studies,ISSN 2543-7097, \#2(2). 345-365 p. [in Ukrainian].

\section{Information about the Authors:}

Iryna Fyshchuk: National Academy for Public Administration under the President of Ukraine, 20, Ezhena Pottier st., Kyiv, 03057, Ukraine

Giese Roland: Doctor of economics, Professor University of Applied Sciences Zittau-Görlitz, Germany

Tussupova Layla: Doctor of economics Professor, Turan University, Kazakhstan

\section{E-mail: sententia.hsk@gmail.com}

